\title{
CHILDHOOD AND ADOLESCENT OBESITY
}

A Systematic Review of Childhood and Adolescent Obesity

Olayiwola Olabisi Rukayat

Bachelor's Thesis

Degree Programme in Nursing

Bachelor's in health care and Social Science

Nursing

2020 


\section{Abstract of Thesis}

Author

Supervisor

Commissioned by

Title of Thesis

Number of pages
Olabisi Olayiwola

Year

2020

Seppo Ikalainen and Tarja Lipponen

Lapland University of Applied Sciences

Childhood and Adolescent Obesity

36 pages

Obesity is the state of being overweight, it is now a public health catastrophe that has become a worldwide epidemic and so raises world concern with childhood obesity quickly turning into a very important public health concern. This thesis aims at providing helpful data which will facilitate the general public in addition to stakeholders in understanding effects of sedentary lifestyle on childhood and adolescent obesity and to acknowledge the factors which might be eased so as to forestall childhood blubber. This can be attributed to an increase in prevalence of childhood obesity as noted by a world health organization study in Finland in 2013.

A systematic literature review was implemented. This method was used to comprehensively identify and include available literature about childhood and adolescent obesity. Articles were carefully scrutinized, using the research question then employed deductive content analysis to extract the data. Studies published with regards to adolescent and childhood obesity in the last decade were included. Studies which were not related to the research topic were excluded.

Sedentary lifestyle has a direct effect on parental purchases and therefore increases in Body Mass Index. Television viewing being the most predominant environmental factor, whereby an enumeration of the relationship between dietary intake and television or other devices used for viewing hours in numbers, indicated a 27\% likelihood of an increase in Body Mass Index among the children. This has a relative effect in comparison to physical activity during this period.

Keywords: Obesity, Sedentary lifestyle, Diet, Childhood and Adolescent. 
Table of Contents

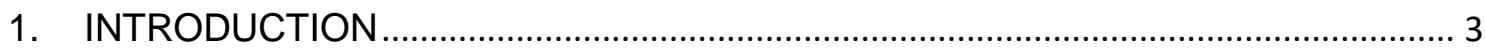

2. CONCEPT OF CHILDHOOD AND ADOLESCENTN OBESITY .................................. 5

2.1 Homeostatic Theory of Obesity: ................................................................................ 5

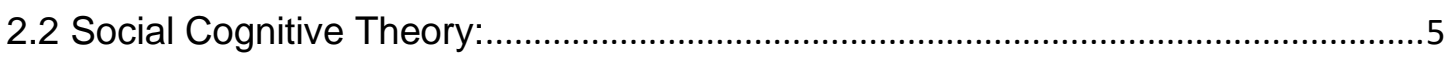

2.3 Inactive life:

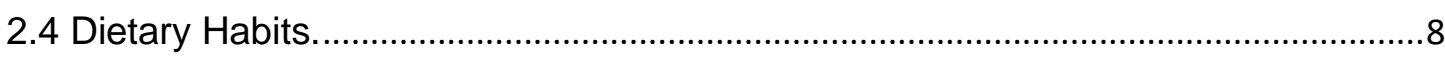

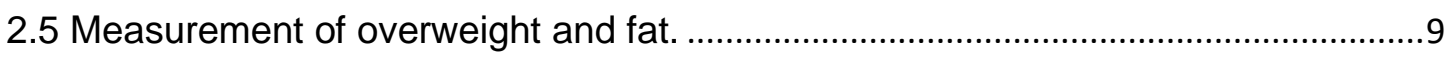

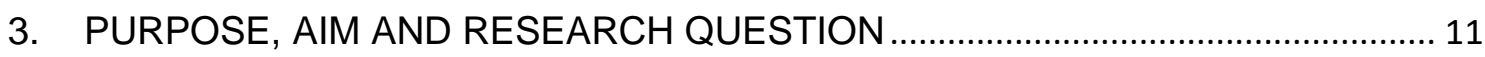

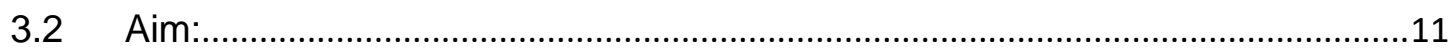

3.3 Research Question:

4. NATURE OF THE RESEARCH AND METHODOLOGICAL SOLUTIONS .............11

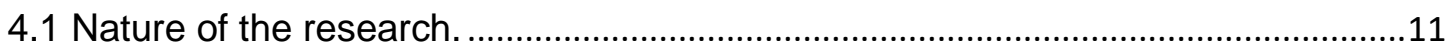

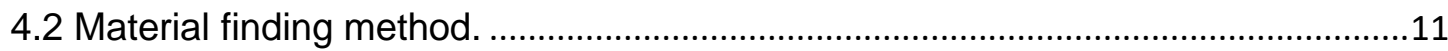

4.3 Inclusion and Exclusion Criteria ...............................................................................

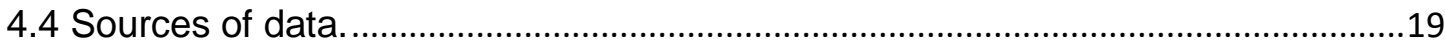

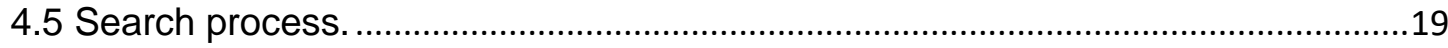

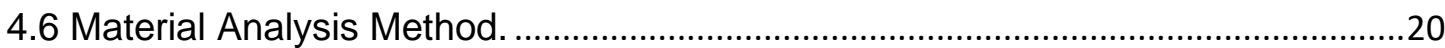

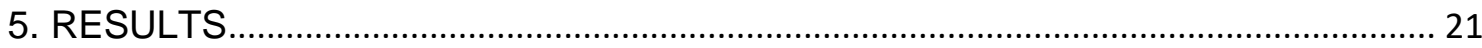

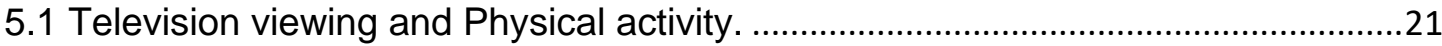

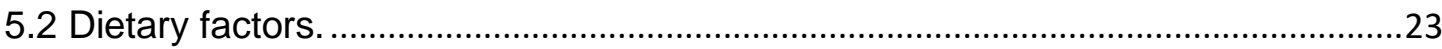

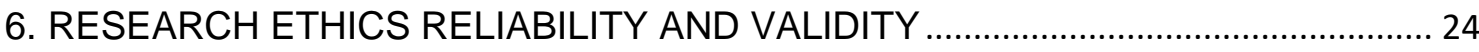

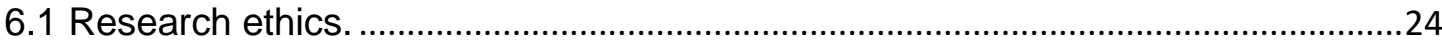

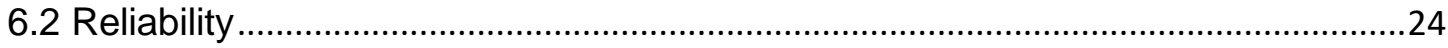

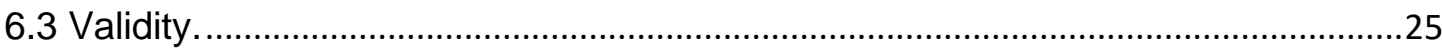

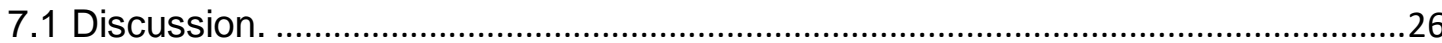

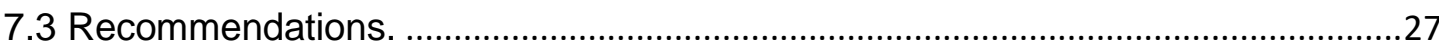

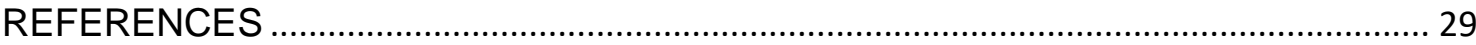




\section{LIST OF ABBREVIATIONS}

BMI: Body Mass Index.

WHO: World Health Organization.

CDC: Centers for Disease Control and Prevention.

NCDs: Non Communicable Diseases

FAO: Food and Agriculture Organization 


\section{INTRODUCTION}

Obesity is the state of being overweight. It will increase the chance of great health conditions, as well as disorders; cardiovascular disease, cancer and diabetes mellitus (United for Sight, 2018).

The World Health Organization world nutrition targets for 2025, features a specific specialize in preventing a rise in childhood blubber. It is calculable that by the year 2025, lifestyle-related non-communicable illness can account for $60 \%$ of the burden of disease, and $70 \%$ of deaths worldwide, if adequate health promotion intervention programs don't seem to be established to cut back this chronic illness burden, modification of one's mode of livelihood, promotion of hindrance measures against non-communicable diseases and improved dietary habits and physical activity are necessary (WHO, 2017).

Moreover, a cause for public health concern is that the increasing trend of kid and adolescent weight gain as they transition into adulthood. Adolescents, aged between 10-19 years, as outlined by the World Health Organization, are targeted for interventions because it is throughout this growth and development duration that health attitudes, beliefs and behaviors are established and continue into adulthood. The adolescent years are noted because the "tipping years", wherever co-morbidities like high pressure, diabetes, stroke, disorder and cancer could seem as short health consequences (HanveyAN, 2017).

Nevertheless, considering many reasons why children and adolescent face this challenge of obesity. A myriad of factors play significant roles in children and adolescent's health, such as transport to and from school; buses, train, instead of walking and also the use of elevator. Increased screen time has become a prevalent habit such as use of: television, phones, iPad, tablets and video games thus contributing to reduced physical activity.

This thesis aims at providing helpful guidelines for nursing student, nurses and society as a whole. The highest risk of children and adolescent obesity are discussed extensively, and so the possible recommendations as well. However, data which will facilitate the general public in addition to stakeholders on varied ways of managing childhood and adolescent obesity. To even be ready to acknowledge the factors which might be eased so as to forestall childhood and 
adolescent obesity as used respectively. It is very essential to understand what it entails, the meaning of obesity and how it can be prevented in the society and most importantly in Finland.

A major increasing trend within the world prevalence of childhood obesity has been documented in kids and adolescents over the previous few decades. Worldwide,22 million and more youngsters less than 5 years and and155 million kids of school going age were severely overweight. This suggests that one in 10 kids worldwide were overweight. This world average reflects a large vary of prevalence levels, with the prevalence of overweight in Africa and Asia averaging well below $10 \%$ and within the Americas and Europe higher than 20\% (WHO, 2013)

Mostly in Finland and other countries in general,you would meet a lot of kids at the shop buying candies and different kinds of junk food without any proper supervision, thus having poor nutrition habits. In terms of prevalence of overweight in adolescents, up to $29 \%$ of boys and $17 \%$ of ladies among 11 -yearolds were overweight, in step with knowledge from the Health Behavior in School-aged kids survey of 2009/2010. Among 13-year-olds, the corresponding figures were $25 \%$ for boys and $17 \%$ for ladies, and among 15 -year-olds, $20 \%$ for boys and $12 \%$ for girls. (WHO, 2013)

With the purpose of contributing to the nursing field, to be more specific the field of pediatric nursing a better understanding regarding this emerging worldwide catastrophe has to be undertaken.

A systematic literature review will be used in this research, to enable find answers for research questions about the particular problem as well as analyzing and enabling a better understanding of existing research to practitioners. The literature review will be conducted on existing literatures available in reliable scientific databases such as ResearchGate and ScienceDirect. The collected data will be analyzed using thematic analysis that will identify similar themes in the research materials. The research theme is obesity among children.

This research have discovered that obesity is among the non-communicable diseases (NCDs) that kills 41 million people each year which comprise of $71 \%$ of the global deaths. The recommendations from this thesis can be considered for 
application in varied policies resulting in a triple-crown outcome in promoting healthy living amongst kids and adolescents by lowering the prevalence and eliminating the avertable factors related to childhood obesity.

\section{CONCEPT OF CHILDHOOD AND ADOLESCENTN OBESITY}

This explains the whole ideas that builds up the thesis in terms of the theories that are implemented, the lifestyle, nutritional part and most importantly the measurement. The homeostatic theory of obesity and social cognitive theory talks mainly of the theory behind childhood and adolescent obesity. However, the impact of lifestyle, nutrition, and measurement to guide regarding obesity cannot be left out. That is why all these are explained extensively.

\subsection{Homeostatic Theory of Obesity:}

Health theorists assert that health is controlled by homeostasis, a present characteristic in all living organisms for maintaining equilibrium. Homeostasis is necessary for the optimum functioning of our bodies. Homeostasis imbalances result in obesity. The Homeostatic Theory of Obesity links the circle of discontent to weight gain. Mark's (2015) research asserts that homeostasis theory explains the cause of obesity in children and adolescents since homeostasis controls all health conditions, including obesity, among other sicknesses. The Food and Agriculture Organization (FAO) says that the world produces two times the required food, yet over 800 million people are underfed. The statistics indicate a significant inequality in food supply (Mark, 2015). The inequality could explain the possibility of obesity among the oversupplied group.

\subsection{Social Cognitive Theory:}

The study's appropriate methodology is that the question ought to correlate with existing analysis queries and theory. The theoretical framework is supposedly the rationalization of the theories relating to behavioral changes, emotional and environmental factors, concerning childhood and adolescent fat. Social Cognitive Theory can explain the result of obesity in children. it also explains behavioral change in human beings and the resultant health effects. Selfefficacy, behavioral capability, and self-control are among the primary concepts 
of social cognitive theory. The self-control concept explains how children cannot control their activities, which results in unhealthy diets resulting in obesity.

Social cognitive theory synthesizes ideas and processes from behavioristic and emotional models of behavior change. The theory, therefore, applies to biological process intervention for illness interference and management. A basic premise is that people learn not only through their own experiences but also by perceiving others' actions and conjointly the results of those actions.

Critical constructs of social cognitive feature theory relevant to biological process intervention embody practical learning, reinforcement, self-control, and self-efficacy. Principles of psychotherapy that have typically been accustomed to promote dietary change are derived from social cognitive theory. Some elements of activity dietary interventions supported social cognitive theory constructs of self-control, reinforcement, and self-efficacy embody goalsetting, self-monitoring and activity obtaining (Glanz, Rimer, and Lewis (2012).

Social Cognitive Theory is one of the foremost often applied theories of health behaviour (Plotnikoff et al., 2013). The theory depicts a reciprocal settled relationship between the individual, his or her surroundings, and comportment; all three elements dynamically and reciprocally move with and upon one another to form the premise for conduct, nevertheless as potential interventions to vary behaviours (Bandura, 1986; Glanz et al., 2014).Qualified pediatric nurse practitioners play a key role in primary, secondary, and tertiary prevention of childhood obesity.

In accordance with the American Academy of Pediatrics, a valuable way to prevent childhood obesity is for providers to include an obesity prevention discussion with parents during each well-child examination with regard to an ambulatory setting (Tyler et al., 2014). Social Cognitive is ideal for use by nurses and pediatricians to inspire behavioral change that will result in flattened obesity cases.

While undertaking management of childhood obesity, the pediatric nurse plays an important role for the patient and the family. In accordance with the American Academy of Pediatrics recommendations on family and patient centered care, the pediatric nurse has to ensure that a collaborative relationship exists with the patient and family and educate them as to why their active 
participation is essential to the child's success in an identified weight management program. (Sorg et al., 2013).

The Pediatric nurse has to take control of the child's health and be an advocate towards their health seeking behavior as this is key in forming a collaborative bond with the patient as well as the family, thus promoting safe patient care and improving outcomes in the long run.

\subsection{Inactive life:}

Overweight and obesity are results of positive energy balance. Low levels of physical activity and/or dietary behaviours that deviate from recommended unit of measurement are thought to contribute to the ethnology of obesity. Children spent longer observing television, tablets, iPad and enjoying video games on weekends than on weekdays. Boys spent longer durations than girls, and younger children of every sexes spent less time than older ones in these activities. These inactive activities like watching television are typically associated with excess weight. In fact, screen time competes with physical activity time, leading to reduced levels of exercise in children.

Besides the association between screen time and overweight/obesity, food intake throughout this activity can build this association even more than necessary. (CatarinaVasques et.Al., 2012). Significantly it is thought that television advertising induces the acquisition of non-nutritious, "junk" foods by folks who sporadically do so due to pressure from their children.

In younger children, overweight/obesity seems to mixture in families. The daily pattern of parents' physical inactivity and activity can influence their children's conduct. At older ages, as children become plenty of freelance, their choices are typically influenced by their peers than by their folks. (S.A. Pereira et.Al., 2010). With the arrival of contemporary technology and totally different fashionable convenience devices, the majority of populations are leading plenty of inactive life vogue compared to the previous generations.

The particular method of transport play a serious role in children and adolescent's health. Infrastructure can dictate suggests that of transportation and area walkability, that's associated with weight standing. High vicinity walkability is often 
associated with attenuate prevalence of overweight and fat, which could link back to structural variations between rural and urban areas.

An extremely recent US study depicted that transport-related physical activity reduced by $17.8 \%$ between 1965 and 2009, that may be attributable to growing presence of automotive possession and certificatory infrastructure for automotive transport. (Alexandra Lee et.Al., 2019)

Activities like getting to school are going to be a physical activity, since some children walk or cycle, but in some children, the car is usually the foremost common reasonable transportation. Younger children walk to middle school less oft than older children. At younger ages, folks generally take children to and from school, primarily by automotive.

The common use of mechanical ways of transportation to go to school has expounded to a lower level of energy expenditure, contributing to inflated overweight and fat in children. (S.A. Pereira et.Al., 2010).

\subsection{Dietary Habits.}

The frequency and sort of food vendors in a given environment determines the kinds of foods that residents should buy. Traditionally, proof has advised that fast food availability density is related to fat prevalence. (Maddock, 2004). Individual-level factors will move with designed environmental factors like fast food vendor density to extend the percentages of fat. Children residing in these neighborhoods have higher odds for obesity than people who live in an exceedingly low-density fast food vendor neighborhood (Li F et.Al., 2009). On the opposite hand, recent analysis suggests that fast food vendor density isn't related to fat prevalence and therefore the food consumed in these establishments' accounts for fewer than $20 \%$ of the whole energy intake (Mazidi M. et.Al., 2017). This might mirror the widespread convenience of fast foods, that weakens the flexibility to dissect links between its presence and raised consumption specific to fat.

Food desert designation has been completely coupled to fat and easily change from a non-food desert census tract to a food desert census tract will increase 
the percentages of fat by $30 \%$, once all different relevant factors squarely measure constant (Chen et al., 2016).

In addition to food convenience and quality, the shift in food kind, amount, and valuation is additionally relevant to the fat epidemic. Offered proof powerfully supports a larger risk of weight gain with raised consumption of sugarsweetened beverages (Hu, 2013). Additionally, fast foods, snack foods, and foods offered through convenience stores happen to be generally ultraprocessed that means they're high in processed grains and supplemental sugars; low in fiber and unsaturated fats. A recent study found that meals that were ultra-processed resulted in larger food intake and weight gain over a twoweek follow-up compared to consumption of non-processed foods (Hall KD et. al., 2019).

Contributing to raised intake of fast-foods and ultra-processed foods is that the selling techniques enforced by food industries across multiple mediums, experimental studies with kids turn out a moderate impact size for raised food consumption once exposed to food advertising (Boyland et.., 2016).

Food advertising targeted at kids is concentrated on complete building and emotional messages might not be discerned intrinsically by this vulnerable population. Another common thought tackling shoppers is that healthy foods are expensive, however analysis suggests this perception is predicated on deceptive worth metrics likewise as changes in fruit and vegetable convenience and level of readiness. Worth per calorie metrics show fruits and vegetables to be luxurious than less healthy foods; but, worth per average portion and worth per edible a hundred grams really shows that fruits and vegetables square measure more cost-effective (Carlson A et., al. 2014). In times of monetary constraint, socioeconomically deprived teams maximize energy worth for cash leading to energy-dense, nutrient poor diets that contribute to fat (Lee A, 2014).

\subsection{Measurement of overweight and fat.}

Body fat distribution is measured and calculable using varied ways. These ways are a variant from the straightforward measuring measurements like weight and height, from that the body mass index (BMI) is derived; waist circumference, waist-hip-ratio, and skin fold thickness to a lot of refined and complex measures 
that square measure largely employed in analysis. They embrace Hydro measurement, resonance Imaging (MRI), computed tomography (CT), twin Energy X-ray Absorptiometry (DEXA), Bioelectric resistance analysis (BIA) and Air Displacement Plethysmography (Mbochi, 2010).

Body mass index may be a straightforward index of weight-for-height, ordinarily accustomed classify overweight and fat. It's a personality's weight in kilograms divided by the sq. of his height in meters $(\mathrm{kg} / \mathrm{m} 2)(\mathrm{WHO}, 2018)$.

The BMI cut-off ranges are reckoned on the associations between BMI, chronic diseases and mortality rates (Mbochi et al., 2012).

The internationally recognized and accepted BMI ranges as adopted by the United Nations agency for the estimation of overweight and fat in Europe is as shown within the

\begin{tabular}{|l|l|}
\hline Below 18.5 & Underweight \\
\hline $18.5-24.9$ & Normal weight \\
\hline $25.0-29.9$ & Pre-obesity \\
\hline $30.0-34.9$ & Obesity class I \\
\hline $35.0-39.9$ & Obesity class II \\
\hline Above 40 & Obesity class III \\
\hline
\end{tabular}

\begin{tabular}{|l|l|}
\hline BMl & Nutritional status \\
\hline
\end{tabular}

Source: World Health Organization (2018)

Of importance to notice is that a rise within the $\mathrm{BMI}$ is directly proportional to the chance of developing some non-communicable diseases. These embrace premature death, vessel diseases, high pressure level, arthritis, some cancers and polygenic disease (WHO, 2018).

The BMI is incredibly extremely however not accurately related with body fat mass, creating it to own many limitations. First and foremost, it doesn't distinguish lean mass from fat mass. Secondly, it doesn't essentially mirror the body fat distribution (Mbochi, 2010). 


\section{PURPOSE, AIM AND RESEARCH QUESTION}

\subsection{Purpose}

The purpose of this project work is to have a better understanding about the associated factors, management and prevention of obesity in children and adolescent.

\subsection{Aim:}

To augment more awareness measures on how to deal with childhood and adolescent Obesity.

\subsection{Research Question:}

What is the relationship between sedentary lifestyle and obesity in children and adolescents?

\section{NATURE OF THE RESEARCH AND METHODOLOGICAL SOLUTIONS}

\subsection{Nature of the research.}

The research employs both a quantitative and qualitative study design. Quantitative methods are ideal for analysing complex statistical data (Kaur et al., 2019). A qualitative design is on the other hand ideal for collecting and analysing descriptive data (Kaur et al., 2019). Qualitative research most of the time add a complex array of data achieved from different sources and a diversity of methods. According to nursing research $9^{\text {th }}$ edition, the tendency has sometimes been described as bricolage and the qualitative researchers has been referred to as Bricoleur, which means adept at performing a plethora of tasks that include; interviewing, in-depth reflection as well as introspection (Denzin\& Lincoln, 2000).

4.2 Material finding method.

The definition of literature review according to one scholar is "the comprehensive study and interpretation of literature that relates to a certain topic" (Aveyard, 
2014). A systematic literature review will be undertaken, the database search for literature review is about searching, having articles that is enough. Then after searching, there would be a limit in narrowing down to the exact materials that would be needed such as, narrowing down research to the geographical area or a particular topic. Also, with the use of critiquing studies to get the required materials that are needed through the research to that certain topic. It is also said that the qualitative researchers has dissimilar opinion about rechecking the literature before implementing a new study.

Already written literature reviews are accepted for many purposes with different functions, and therefore the usefulness of the product would be determined by its length. A literature review is a state-of-the-art documentation with respect to the subject or topic you are writing about it surveys the literature in the chosen area of the study.

The rise in childhood obesity has becomes a disturbing trend. Health care providers have the unique opportunity to not only treat, but prevent childhood obesity. Primary care providers are capable of providing care to these children; so why aren't they?

Health care providers should enable evaluation and awareness to patients and their families to help decrease the incidence of childhood obesity. Primary care providers must take action so that our patients can become more informed about obesity, furthermore they should be able to position themselves as role models and educators for their families, communities, and patients.

Guidelines are preferred in treatment of childhood obesity by $69 \%$ of physicians, trailed by Basal Mass Index growth charts (57\%) and continuous medical education courses (55\%) (Nicholas et.Al., 2009).

Further documentation from the same study found that after a toolkit was provided, the intervention group increased the use of BMI percentiles significantly in the two-through five-year-old age group and approached significance in the six-through twenty-year-old age group (Nicholas et al., 2009).

Providers that participate in obesity related continuing education were found to be more familiar with the recommendations (Sesselberg et al. 2010) 
In another documented study a conclusion was made that participation in community engagement and education has been associated with better adherence to current evidenced-based guidelines. (Sesselberg et al. (2010).

Education of primary care providers is extremely important in order to deliver the most up-to-date care for patients. Providing education can offer a simpler approach to the guidelines and therefore increase the usage of the guidelines. With proper education Health Care Providers have the unique opportunity to play a critical role in replacing the obesity epidemic with a trend toward wellness.

The widespread presence of obesity and even overweight has increased drastically in every society around the world in the last three decades. The likelihood of the continuation of this health challenge is probably going to progress in the next coming years if adequate care is not taken.

\subsection{Inclusion and Exclusion Criteria}

Searches were conducted in qualitative studies that were specifically devoted to factors associated with childhood and adolescent obesity that have been published in the last decade with English-language restriction and abstracts were included in the thesis. Study materials not addressing the target topic, investigating the associated factors mainly sedentary lifestyle and obesity were excluded. In case of the updated of journals, the study included only the latest version published.

Table 1: Inclusion and exclusion criteria

\begin{tabular}{|l|l|}
\hline \multicolumn{1}{|c|}{ Inclusion Criteria } & \multicolumn{1}{|c|}{ Exclusion Criteria } \\
\hline $\begin{array}{l}\text { Studies which are relevant to } \\
\text { childhood and adolescent obesity. }\end{array}$ & $\begin{array}{l}\text { Studies which are not related to the } \\
\text { research topic. }\end{array}$ \\
\hline Studies in English language. & Studies in other languages. \\
\hline $\begin{array}{l}\text { Studies that are in full text which has } \\
\text { free access to read and use the data. }\end{array}$ & $\begin{array}{l}\text { Studies not in full text and did not } \\
\text { match the keywords of the research } \\
\text { topic. }\end{array}$ \\
\hline
\end{tabular}




\begin{tabular}{|l|l|}
\hline $\begin{array}{l}\text { Research articles must be evidenced- } \\
\text { based. }\end{array}$ & $\begin{array}{l}\text { Non-evidence-based research } \\
\text { articles. }\end{array}$ \\
\hline Studies conducted from 2009 to date. & Studies conducted before 2009. \\
\hline $\begin{array}{l}\text { studies that used qualitative and } \\
\text { quantitative methods }\end{array}$ & $\begin{array}{l}\text { Studies in general population } \\
\text { exploring prevention of obesity or } \\
\text { social representations of obesity in } \\
\text { children and adolescents. }\end{array}$ \\
\hline $\begin{array}{l}\text { Studies that interviewed obese } \\
\text { children and adolescents, parents of } \\
\text { obese children and adolescents, } \\
\text { health care providers for obese } \\
\text { children and adolescents }\end{array}$ & \\
\hline
\end{tabular}

The articles selected include;

\begin{tabular}{|c|c|c|c|c|}
\hline Reference & $\begin{array}{l}\text { Article } \\
\text { Name }\end{array}$ & $\begin{array}{l}\text { Resea } \\
\text { rch } \\
\text { Metho } \\
\text { d }\end{array}$ & $\begin{array}{l}\text { Key } \\
\text { Results }\end{array}$ & $\begin{array}{l}\text { Conclu } \\
\text { sions }\end{array}$ \\
\hline $\begin{array}{l}\text { Boyland, E., Nolan, S., Kelly, B., } \\
\text { Tudur-Smith, C., Jones, A., Halford, } \\
\text { J., \& Robinson, E. (2016). } \\
\text { Advertising as a cue to consume: a } \\
\text { systematic review and meta-analysis } \\
\text { of the effects of acute exposure to } \\
\text { unhealthy food and nonalcoholic } \\
\text { beverage advertising on intake in } \\
\text { children and adults. American } \\
\text { Journal Of Clinical Nutrition. }\end{array}$ & $\begin{array}{l}\text { Advertisin } \\
\mathrm{g} \text { as a } \\
\text { cue to } \\
\text { consume: } \\
\text { a } \\
\text { systemati } \\
\mathrm{c} \text { review } \\
\text { and } \\
\text { meta- } \\
\text { analysis } \\
\text { of the } \\
\text { effects of } \\
\text { acute } \\
\text { exposure } \\
\text { to }\end{array}$ & $\begin{array}{l}\text { Mixed } \\
\text { Metho } \\
\text { ds }\end{array}$ & $\begin{array}{l}\text { No } \\
\text { clear } \\
\text { eviden } \\
\text { ce of } \\
\text { adverti } \\
\text { sement } \\
\text { on the } \\
\text { intake } \\
\text { of food. }\end{array}$ & $\begin{array}{l}\text { Adverti } \\
\text { sement } \\
\text { increas } \\
\text { es food } \\
\text { intake } \\
\text { in } \\
\text { childre } \\
n \text { but } \\
\text { not } \\
\text { adults }\end{array}$ \\
\hline
\end{tabular}




\begin{tabular}{|c|c|c|c|c|}
\hline & $\begin{array}{l}\text { unhealthy } \\
\text { food and } \\
\text { nonalcoh } \\
\text { olic } \\
\text { beverage } \\
\text { advertisin } \\
\text { g on } \\
\text { intake in } \\
\text { children } \\
\text { and } \\
\text { adults }\end{array}$ & & & \\
\hline $\begin{array}{l}\text { Vasques, C., Mota, M., Correia, T., \& } \\
\text { Lopes, V. (2012). Prevalence of } \\
\text { overweight/obesity and its } \\
\text { association with sedentary behavior } \\
\text { in children. } \\
\text { https://www.sciencedirect.com/scien } \\
\text { ce/article/pii/S2174204912002097 }\end{array}$ & $\begin{array}{l}\text { Prevalen } \\
\text { ce of } \\
\text { overweig } \\
\text { ht/obesity } \\
\text { and its } \\
\text { associati } \\
\text { on with } \\
\text { sedentary } \\
\text { behavior } \\
\text { in } \\
\text { children }\end{array}$ & $\begin{array}{l}\text { Qualit } \\
\text { ative } \\
\text { and } \\
\text { quantit } \\
\text { ative } \\
\text { design }\end{array}$ & $\begin{array}{l}\text { There } \\
\text { is a } \\
\text { prevale } \\
\text { nce of } \\
\text { overwe } \\
\text { ight by } \\
22.6 \% \\
\text { and } 9 \% \\
\text { for } \\
\text { obesity }\end{array}$ & $\begin{array}{l}\text { Most } \\
\text { obese } \\
\text { childre } \\
\mathrm{n} \\
\text { spend } \\
\text { their } \\
\text { free } \\
\text { time on } \\
\text { televisi } \\
\text { on }\end{array}$ \\
\hline $\begin{array}{l}\text { Chen, D., Jaenicke, E., \& Volpe, R. } \\
\text { (2016). Food Environments and } \\
\text { Obesity: Household Diet Expenditure } \\
\text { Versus Food Deserts. American } \\
\text { Journal Of Public Health. }\end{array}$ & $\begin{array}{l}\text { Food } \\
\text { Environm } \\
\text { ents and } \\
\text { Obesity }\end{array}$ & $\begin{array}{l}\text { Mixed } \\
\text { Metho } \\
\text { ds }\end{array}$ & $\begin{array}{l}\text { There } \\
\text { is a } \\
\text { relation } \\
\text { ship } \\
\text { betwee } \\
\mathrm{n} \text { food } \\
\text { environ } \\
\text { ments } \\
\text { and } \\
\text { obesity }\end{array}$ & $\begin{array}{l}\text { Food } \\
\text { environ } \\
\text { ments } \\
\text { contrib } \\
\text { utes to } \\
\text { most of } \\
\text { the } \\
\text { obese } \\
\text { cases } \\
\text { in the } \\
\text { world }\end{array}$ \\
\hline
\end{tabular}




\begin{tabular}{|c|c|c|c|c|}
\hline $\begin{array}{l}\text { Clark, B., Sugiyama, T., Healy, G., } \\
\text { Salmon, J., Dunstan, D., \& Owen, N. } \\
\text { (2009). Validity and reliability of } \\
\text { measures of television viewing time } \\
\text { and other non-occupational } \\
\text { sedentary behavior of adults: a } \\
\text { review }\end{array}$ & $\begin{array}{l}\text { Validity } \\
\text { and } \\
\text { reliability } \\
\text { of } \\
\text { measures } \\
\text { of } \\
\text { television } \\
\text { viewing } \\
\text { time and } \\
\text { other } \\
\text { non- } \\
\text { occupatio } \\
\text { nal } \\
\text { sedentary } \\
\text { behavior } \\
\text { of adults: } \\
\text { a } \\
\text { reviewiise }\end{array}$ & $\begin{array}{l}\text { Literat } \\
\text { ure } \\
\text { review }\end{array}$ & $\begin{array}{l}\text { Spendi } \\
\text { ng too } \\
\text { much } \\
\text { time on } \\
\text { Tv has } \\
\text { a } \\
\text { tenden } \\
\text { cy to } \\
\text { result } \\
\text { to } \\
\text { overwe } \\
\text { ight } \\
\text { and } \\
\text { obesity }\end{array}$ & $\begin{array}{l}\text { Tv is } \\
\text { among } \\
\text { the } \\
\text { factors } \\
\text { leading } \\
\text { to the } \\
\text { prevale } \\
\text { nce of } \\
\text { obesity } \\
\text { in } \\
\text { childre } \\
n \text { and } \\
\text { teens. }\end{array}$ \\
\hline $\begin{array}{l}\text { Swinburn, B., \&Vandevijvere, S. } \\
\text { (2016). WHO Report On Ending } \\
\text { Childhood Obesity Echoing Earlier } \\
\text { Recommendations. }\end{array}$ & $\begin{array}{l}\text { WHO } \\
\text { Report } \\
\text { On } \\
\text { Ending } \\
\text { Childhoo } \\
\text { d Obesity } \\
\text { Echoing } \\
\text { Earlier } \\
\text { Recomm } \\
\text { endations }\end{array}$ & $\begin{array}{l}\text { Mixed } \\
\text { metho } \\
\text { d }\end{array}$ & $\begin{array}{l}\text { Exercis } \\
\text { e } \\
\text { reduce } \\
\text { non } \\
\text { commu } \\
\text { nicable } \\
\text { diseas } \\
\text { es } \\
\text { prevale } \\
\text { nce }\end{array}$ & $\begin{array}{l}\text { Increas } \\
\text { ing } \\
\text { exercis } \\
\text { e time } \\
\text { will } \\
\text { help in } \\
\text { reducin } \\
\text { g } \\
\text { obesity } \\
\text { among } \\
\text { childre } \\
n\end{array}$ \\
\hline $\begin{array}{l}\text { Kääriäinen, M., Kanste, O., Elo, S., } \\
\text { Pölkki, T., Miettunen, J., \& Kyngäs, H. } \\
(2011) \text {. Testing and verifying nursing } \\
\text { theory by confirmatory factor }\end{array}$ & $\begin{array}{l}\text { Testing } \\
\text { and } \\
\text { verifying } \\
\text { nursing }\end{array}$ & $\begin{array}{l}\text { Quanti } \\
\text { tative }\end{array}$ & $\begin{array}{l}\text { Health } \\
\text { proble } \\
\text { ms are } \\
\text { related }\end{array}$ & $\begin{array}{l}\text { Social } \\
\text { cognitiv } \\
\text { e } \\
\text { theory }\end{array}$ \\
\hline
\end{tabular}




\begin{tabular}{|c|c|c|c|c|}
\hline $\begin{array}{l}\text { analysis. Journal Of Advanced } \\
\text { Nursing. }\end{array}$ & $\begin{array}{l}\text { theory by } \\
\text { confirmat } \\
\text { ory factor } \\
\text { analysis }\end{array}$ & $\begin{array}{l}\text { metho } \\
\text { d }\end{array}$ & $\begin{array}{l}\text { to } \\
\text { nursing } \\
\text { theorie } \\
\mathrm{s}\end{array}$ & $\begin{array}{l}\text { explain } \\
\text { s how } \\
\text { behavi } \\
\text { oural } \\
\text { change } \\
\text { can } \\
\text { lead to } \\
\text { obesity }\end{array}$ \\
\hline $\begin{array}{l}\text { Li, F., Harmer, P., Cardinal, B., } \\
\text { Bosworth, M., \& Johnson-Shelton, D. } \\
\text { (2009). Obesity and the Built } \\
\text { Environment: Does the Density of } \\
\text { Neighborhood Fast-Food Outlets } \\
\text { Matter?.American Journal Of Health } \\
\text { Promotion. }\end{array}$ & $\begin{array}{l}\text { Obesity } \\
\text { and the } \\
\text { Built } \\
\text { Environm } \\
\text { ent: Does } \\
\text { the } \\
\text { Density } \\
\text { of } \\
\text { Neighbor } \\
\text { hood } \\
\text { Fast- } \\
\text { Food } \\
\text { Outlets } \\
\text { Matter? }\end{array}$ & $\begin{array}{l}\text { Mixed } \\
\text { metho } \\
\text { ds }\end{array}$ & $\begin{array}{l}\text { There } \\
\text { is a } \\
\text { relation } \\
\text { ship } \\
\text { betwee } \\
\mathrm{n} \text { fast } \\
\text { food } \\
\text { shops } \\
\text { and } \\
\text { obesity } \\
\text {. }\end{array}$ & $\begin{array}{l}\text { Increas } \\
\text { ing } \\
\text { fasts } \\
\text { foods } \\
\text { outlets } \\
\text { are } \\
\text { contrib } \\
\text { uting to } \\
\text { the } \\
\text { increas } \\
\text { ing } \\
\text { obesity } \\
\text { cases } \\
\text { among } \\
\text { childre } \\
\text { n and } \\
\text { teenag } \\
\text { ers }\end{array}$ \\
\hline $\begin{array}{l}\text { Pereira, S., Seabra, A., Silva, R., } \\
\text { Katzmarzyk, P., Beunen, G., \&Maia, } \\
\text { J. (2010). Prevalence of overweight, } \\
\text { obesity and physical activity levels in } \\
\text { children from Azores Islands. }\end{array}$ & $\begin{array}{l}\text { Prevalen } \\
\text { ce of } \\
\text { overweig } \\
\text { ht, } \\
\text { obesity } \\
\text { and } \\
\text { physical }\end{array}$ & Mixed & $\begin{array}{l}\text { Obesity } \\
\text { in girls } \\
\text { is } \\
\text { prevale } \\
\text { nt by } \\
22 \% \\
\text { compar }\end{array}$ & $\begin{array}{l}\text { The } \\
\text { prevale } \\
\text { nce } \\
\text { levels } \\
\text { of } \\
\text { obesity } \\
\text { in boys }\end{array}$ \\
\hline
\end{tabular}




\begin{tabular}{|c|c|c|c|c|}
\hline & $\begin{array}{l}\text { activity } \\
\text { levels in } \\
\text { children } \\
\text { from } \\
\text { Azores } \\
\text { Islands }\end{array}$ & & $\begin{array}{l}\text { ed to } \\
\text { boys } \\
\text { by } \\
13 \% \text {. }\end{array}$ & $\begin{array}{l}\text { and } \\
\text { girls } \\
\text { shows } \\
\text { that } \\
\text { boys } \\
\text { engage } \\
\text { in more } \\
\text { physica } \\
\text { I } \\
\text { activitie } \\
\text { s than } \\
\text { girls. }\end{array}$ \\
\hline $\begin{array}{l}\text { Sesselberg, T., Klein, J., O'Connor, } \\
\text { K., \& Johnson, M. (2010). Screening } \\
\text { and counseling for childhood obesity: }\end{array}$ & $\begin{array}{l}\text { Screenin } \\
\mathrm{g} \text { and } \\
\text { counselin } \\
\mathrm{g} \text { for } \\
\text { childhood } \\
\text { obesity }\end{array}$ & $\begin{array}{l}\text { Mixed } \\
\text { Metho } \\
\text { ds }\end{array}$ & $\begin{array}{l}\text { Early } \\
\text { detecti } \\
\text { on of } \\
\text { obesity } \\
\text { among } \\
\text { childre } \\
\text { n helps } \\
\text { succes } \\
\text { sful } \\
\text { treatme } \\
\text { nt }\end{array}$ & $\begin{array}{l}\text { Early } \\
\text { therapy } \\
\text { and } \\
\text { counse } \\
\text { ling } \\
\text { helps } \\
\text { in } \\
\text { reducin } \\
\text { g } \\
\text { obesity } \\
\text { and } \\
\text { overwe } \\
\text { ight } \\
\text { cases } \\
\text { among } \\
\text { childre } \\
\text { n. }\end{array}$ \\
\hline $\begin{array}{l}\text { WHO, 2014.Adolescent obesity and } \\
\text { related behaviors: trends and } \\
\text { inequalities in the WHO European } \\
\text { Region. }\end{array}$ & $\begin{array}{l}\text { Adolesce } \\
\text { nt obesity } \\
\text { and } \\
\text { related } \\
\text { behaviors }\end{array}$ & $\begin{array}{l}\text { Qualit } \\
\text { ative } \\
\text { (obser } \\
\text { vation) }\end{array}$ & $\begin{array}{l}\text { There } \\
\text { is a } \\
\text { notable } \\
\text { inequal } \\
\text { ity in }\end{array}$ & $\begin{array}{l}\text { Rich } \\
\text { families } \\
\text { kids } \\
\text { have } \\
\text { high }\end{array}$ \\
\hline
\end{tabular}




\begin{tabular}{|l|l|l|l|l|}
\hline & $\begin{array}{l}\text { : trends } \\
\text { and } \\
\text { inequaliti } \\
\text { es in the } \\
\text { WHO } \\
\text { European } \\
\text { Region }\end{array}$ & food & obesity \\
supply & cases \\
in the & compar \\
Europe & ed to \\
an & needy \\
regions & families \\
. The \\
disparit \\
y can \\
be \\
explain \\
ed by \\
the \\
social \\
inequal \\
ities. \\
\end{tabular}

\subsection{Sources of data.}

Established methods of data searching were employed with data extraction from a range of disciplines and academic data bases including; CENTRAL (Cochrane Library); CINAHL (Ebsco); Medline (Ebsco); PubMed, PMC, ScienceDirect, and ResearchGate

The NURSH (nursing subject heading) term being used was 'sedentary lifestyle in childhood and adolescent obesity' together with identified keywords, such as 'associated factors'; 'prevalence'; 'prevention measures'; 'television viewing'; 'pediatric nursing in childhood obesity'; 'childhood and adolescents obesity in Finland and Europe'; 'trends in childhood and adolescent obesity'; 'Diet'; 'comorbidities in childhood obesity'; 'nurses' and 'health care providers role in childhood obesity'.

\subsection{Search process.}


Various Search terms were employed to identify all studies that report findings on childhood and adolescent obesity derived from. The search process used a similar theme for all articles. Search words included obesity among children and relationship between obesity and television.

Along with the keywords, screening tools were used in each database including; the inclusion criteria such as publication year and full-text articles with free access, synonyms, word variants, database labels, so as to exclude studies not meeting our criteria. Only English language studies were included.

\subsection{Material Analysis Method.}

As defined by a scholar, data analysis is a process of conjecture and verification, of correction and modification, of suggestion and defense (Polit and Beck 2012, pp.557). The main objective of data analysis is to provide a path for organization, structuring and visualization of meaning from the data.

For this study thematic analysis was used to analyze the data obtained during the study and to present the results of the findings. Content analysis is "the dissection of the content of narrative data to identify prominent themes and patterns among the themes as well as the process of organizing and integrating material from documents, often narrative information from a qualitative study, according to key concepts and themes.

This method of data analysis involves breaking down data obtained into smaller units, coding and giving names to the unit corresponding to the content which they represent, and grouping coded materials based on similar concepts or ideas.( Polit and Beck 2012, pp.564,723). Even though content analysis usually involves numerous coding, it is crucial to emphasize that the results are organized under the three main objectives of the study.

Researchers familiarized themselves with selected articles via research methods and findings/ results of selected papers, because it is important that researchers gain a sufficient general understanding of the findings and conclusions of each papers. "Generic questions to ask about each section of a research paper" in Moule and Goodman's Nursing Research: An Introduction (2013,118 \& 131) was used as a reference for appraisal. 
Reading of the articles was done solely, after which findings were analyzed to ensure all relevant and important information had been collected. The reading of the result sections of each of the selected articles were particularly focused to identify themes, categories and sub-categories.

In content analysis the dissection and reporting technique should purpose to enumerate findings in a sensible manner for the readers and in a way that it can be useful. However, the all fundamental element of qualitative study designs which is the presentation of findings has been given minimal attention. (Sandelowski \& Leeman, 2011).

Reporting of results of content analysis is particularly linked to transferability, conformability, and credibility. Results should be reported consistently and precisely with attention to detail paid to how interactions between the data and results are reported. However, the reporting of results consistently has often been a challenge (Kyngäs et al., 2011).

In this study findings from each article were interpreted, summarized and presented according to the main objective of this study.

\section{RESULTS}

Key sedentary behaviors that were analyzed in this study included: television watching, physical activity and diet.

\subsection{Television viewing and Physical activity.}

The relationship between time spent on television and obesity has been reported in several research studies (Wilkerson et al, 2012).

Children's television viewing has a direct effect on parental purchases and therefore increases in Body Mass Index. Research suggested that high sugar, highly fatty foods were the most asked for by children and are the most purchased by parents. An enumeration of the relationship between calorie intake, television viewing hours in numbers, nourishments that were asked for and obtained and the regularity of viewing while eating. The result of this research indicated a $27 \%$ likelihood of an increase in Body Mass Index among the children (Taras et al. 2011). 
A study of 3-to 12-year-old children found that significant inversely-related predictors for childhood obesity were:

- Relative elevation of numbers in terms of athletic hours

- Regular television viewing.

In the case of watching television, the number of times that classes taught children about healthy nutrition $(p<0.05)$ and self-control for watching less than two hours of television $(p<0.07)$ were significant predictors (Wagner et al, 2014).

The mean number of hours of television watching was found to be 3.51, with $66.5 \%$ viewing less than two hours of television. The percentage of students who watched three or more hours of television per day was $36.2 \%$, as compared to Centers for Disease Controls national data of 39.5\% (CDC, 2015).

Physical activity plays an important role in childhood obesity and has always been associated with television viewing and other screen time activities. Through the Framingham Children Study in a study to elicit the relationship between physical action and change in obesity over an 8-year period. The researchers used activity and anthropometry measurement for 106 youths to examine the impact of the physical work on changes in the muscle to fat ratio ratios from preschool elementary.

The results showed that children who had regular participation in activity of the typical daily movements from ages 3 to 12 years had lower Basal Mass Index, triceps, and an accumulation of five skinfold all through adolescence. By age 12, the total of five skinfold was $94.8,96.1$, and 76.3 for small, center, and high physical activity. The effectiveness was evident for both boys and girls. The mean $\mathrm{BMI}+\mathrm{SE}$ for the low, direct, and high action gatherings were $22.4+1.6,20.8+$ 0.6 , and 17.9+ 0.4, respectively (Moore et al. 2012).

This was a clear demonstration that larger amounts of physical activity in adolescence leads to the development of less fat to muscle ratios. In a study inspecting physical movement in preschool children identified as overweight. A sample of 245 children from three to five years of age and their parents (241 mothers and 175 fathers) from ten preschool destinations. They surveyed physical movement at preschool on various days, utilizing two independent measures. (Pate et. al., 2013). 
Parents filled a questionnaire that looked at socio-demographic data, height and weight of the parents, a depiction of physical movement, support for physical activity, dynamic toys, children's television screen time, and recreation park activities. It was revealed that young males depicted as overweight were subsequently less dynamic than their companions who were not overweight and that no critical difference was demonstratable in young females. Despite the established connection between adolescents' weight status and parents' obesity, there was no apparent distinction in the influence of parents on physical action. It was presumed that low levels of physical movement made children be at risk for obesity (Pate et.Al. 2013).

\subsection{Dietary factors.}

Food is a major factor in the development of a person throughout the growth and development years. The environment in which the child's lives determine the food behavior and quality of nutrition. (Wabotsch, 2010). School going children and adolescents require three meals and consume snacks twice in a day. Majority of the respondents (61\%) consumed food three times in a day while (17.4\%) consumed food two times in a day, $16.7 \%$ ate any time of the day and $4.9 \% \%$ ate once in a day. (Sterneck, 2009).

Skipping meals has a big effect on the eating habits of an individual, which often results in less food intake or excessive food consumption. In a study it was indicated that (46\%) of children did not eat supper while (41.4\%) skipped breakfast. The results also showed that (8\%) skipped lunch while only (4.6\%) did not skip any meal. The reasons that were given for skipping meals included: Minimal eating time, lack of appetite, illness, doing late night snacks and snacking in between meals. (Lilian et.Al., 2009)

Across races in a study in the USA, it was identified that vegetables and organic products uses was essentially different among ethnic gatherings. A self-reporting survey report was used and it utilized the Behavioral Risk Factors Surveillance System 2015. The effects of eating vegetables five or more times each day were less pronounced in females than in males. Ethnic gatherings who reported eating five or more vegetables per day were Caucasians (17.3\%), African American (12.7\%), Hispanic Americans (5.5\%), Native American (29.2\%), Asian Pacific Islander (18.5\%), and others (16.8\%) (CDC, 2015). 


\section{RESEARCH ETHICS RELIABILITY AND VALIDITY}

\subsection{Research ethics.}

Every study pertaining to human beings and animals requires ethical issues. In regards to research, ethics must be put into consideration. The validity and reliability of the work is very important, therefore reliable sources must be used in this work and also the materials that would be used has to be valid and within the set time. There should be lots of scientific foundation and standard as well as ethical principles to my own research. In nursing research, there are some important factors to be considered.

First of all, respect for people, people that participated needs to be autonomous, and those that are not autonomous need to be protected. Secondly, beneficence; nurses and other researchers should practice kindness and empathy when dealing with patients in any form or when relating with patient or details that concern patients. In order words, it is a way of saying the code of ethics in nursing are followed accordingly. Thirdly, justice; is it said that when articles or journal are been published but needs to be paid for before the rest of the public can access it. It is known that the system is not favourable enough because those materials need to be available for more understanding of some medication conditions and their possible solutions.

\subsection{Reliability}

In qualitative research the definition of reliability is challenging and its knowledge contradictory. Thus, in understanding the essence of reliability for qualitative research lies with consistency.(Gunawan, 2015). A variability difference for results can be allowed in qualitative research with a provision that the methodology and knowledgeable logistics in a consistent basis yield data that are philosophically similar but may differ in richness and ambience within interchangeable dimensions. (Grossoehme,2014)

It has been proposed that five methods can be used in ensuring the reliability of process and the results obtained: Refutational analysis, constant data comparison, comprehensive data use, inclusive of the deviant case and use of tables. (Silverman, 2009) 
Reliability can be evaluated in terms of predisposition of a study to be replicated without affecting the content material results. This study has very specific and comparable objectives in terms of research questions which adds to its reliability. Moreover, the criterion that was set in the selection of the study articles allowed narrowing down to specific articles hence biases were omitted. To this regard, a conclusion with similar results as our reviewed articles was arrived at.

Lapland University of Applied Sciences provides reliable databases that we were able to use to collect related articles on this research study. Possible database to retrieve evidenced-based articles for this research were from PubMed, PsycINFO, CINAHL, EMBASE, MEDLINE, Endocrinology abstracts, International Bibliography of the Social Sciences, Dissertations \& Theses Full Text and Dissertations \& Theses Global.

\subsection{Validity.}

Validity as defined in qualitative research highlights suitability of the material tools, processes, and data. Whether the research question is valid for the specified outcome, the selection of methodology is acceptable for answering the research question, the planning is valid for the methodology, the sampling and data analysis is acceptable, and eventually the results and conclusions are valid for the sample and context. In assessing validity of qualitative research, the challenge can start from the ontology and epistemology of the difficulty being studied, e.g. the concept of "individual" is seen differently between humanistic and positive psychologists due to differing philosophical perspectives.

Where humanistic psychologists believe "individual" may be a product of existential awareness and social interaction, positive psychologists think the "individual" exists side-by-side with formation of any person. Set off in several pathways, qualitative research regarding the individual's wellbeing are going to be concluded with varying validity. The method of choice must enable detection of findings that are within the suitable context for it to be valid, with reference to the variable.(Waterman, 2013)

Validity of a study measures how well a study's method answers its research questions. This study uses a secondary data and therefore the validity of this study highly depends on these studies. Questionnaires developed by researchers 
were pretested this question in a pilot study before their actual applications. Some of the articles reviewed used existing and tested questionnaires in their research. Inclusion and exclusion criteria were strictly adhered to in selection of the articles for this study. With regard to this, we can conclude that the findings of the study are valid.

\section{DISCUSSION, CONCLUSION AND RECOMMENDATIONS}

\subsection{Discussion.}

The Goal of this systematic literacy review was to assess whether patterns of sedentary behavior were associated with child and adolescent obesity. The correlation between inactive comportment and an individual's weight status is often inconsistent and this can be attributed to the moderating effect of food intake during certain types of inactive conducts such as television screen time.

Results show small to moderate reliable association, between sedentary behavior and unhealthy dietary intake. This is evident in higher consumption of high energy snacks and less consumption of fruits and vegetable.

For children, television viewing had a positive association with consumption of high energy snacks and drinks. Sedentary behavior in adolescents is also associated with elements of a less healthy diet, and in particular with higher consumption of high energy snacks. In summary diet and sedentary behavior in young people is coupled and offers a better clarification between sedentary behavior and overweight. There was an apparent demonstration that there is a positive relationship between physical activities and obesity, the more the physical action the probability of obesity was directly proportional to it.

Obesity is a global problem and it could leads to several critical health conditions, like coronary artery disease, diabetes, hypercholesterolemia and so on. That's why nurses needs to be well informed and updated about it from time to time. In nursing, health promotion should be available for the patients and their relative. For obesity, I think it is very crucial that there should be more information about nutrition, eating clean and proper balance diet. This could affect our society positively in preventing from getting sick and maintaining a healthy environment. 
The role of physical activity in people's life cannot be over emphasized, and that can also be joined to health promotion when educating people about the best lifestyle that can help to stay healthy. Personally, I believe I have understood what obesity entails, how to prevent it, and the possible recommendations to help children and adolescent. Measurement and the right values for determining whether a child is obese or not.

\subsection{Conclusion:}

In conclusion, it can be said that;

I. Inactive behavior, which in most instances is evaluated as screen time from television viewing, is a significant associated factor to unhealthy dietary behaviors among children and adolescents.

II. There is nothing wrong in spacing the time of eating but it has to be healthy foods, that is children can eat 3-4 times in a day as long as they are eating proper meals.

III. When more amounts of time are spent on exercises the lower the chances of a child or adolescent has of having obesity.

IV. Interventions are therefore needed to be undertaken so as to target reductions in sedentary time in order to asses if there will be dietary changes.

\subsection{Recommendations.}

Practically in an effort to help improve on the sedentary habits of children the study made the following recommendations:

I. Nutrition awareness should be provided to both parents and their children on healthy nutrition i.e. healthy meals and snacks choices

II. Schools should promote physical activity by ensuring that children are incorporated in a variety of recreational activity and more time spent while exercising.

III. Educational institutions and society should encourage and promote healthy eating through providing and facilitating trainings in practical food skills, ensuring healthy nutrition standards while administering school meals as well as the foods provided in their canteens. 
Nevertheless, the parent should also be involved in the health promotion programs because the children also eats at home.

IV. Interventions should be made in collaboration with parents to target reduction in screen time or provide screen time activities that help lessen chances of obesity. 


\section{REFERENCES}

Abdullah, S. (2019). Social Cognitive Theory: A Bandura Thought Review.

Adab, P., Pallan, M., \& Whincup, P. H. (2018). Is BMl the best measure of obesity? - British Medical Journal.

Ali, P. (2011). Doing a Literature Review in Health and Social Care Helen Aveyard Doing a Literature Review in Health and Social Care.

Aycan, Z. (2009). Obesity in Childhood: definition and epidemiology

Bandura, A. (2004). Health Promotion by Social Cognitive Means. Health Education \& Behavior.

Biddle, S. J., Gorely, T., Marshall, S. J., \& Cameron, N. (2009). The prevalence of sedentary behavior and physical activity in leisure time: A study of Scottish adolescents using ecological momentary assessment. Preventive Medicine.

Boyland, E., Nolan, S., Kelly, B., Tudur-Smith, C., Jones, A., Halford, J., \& Robinson, E. (2016). Advertising as a cue to consume: a systematic review and meta-analysis of the effects of acute exposure to unhealthy food and nonalcoholic beverage advertising on intake in children and adults. American Journal Of Clinical Nutrition.

Carlson, A., \&Frazão, E. (2014). Food costs, diet quality and energy balance in the United States.

Chaput, J., Lambert, M., Mathieu, M., Tremblay, M., O' Loughlin, J., \& Tremblay, A. (2010). Physical activity vs. sedentary time: independent associations with adiposity in children.

Chen, D., Jaenicke, E., \& Volpe, R. (2016). Food Environments and Obesity: Household Diet Expenditure Versus Food Deserts. American Journal Of Public Health. 
Clark, B., Sugiyama, T., Healy, G., Salmon, J., Dunstan, D., \& Owen, N. (2009). Validity and reliability of measures of television viewing time and other nonoccupational sedentary behavior of adults: a review.

Elmore, S., \& Sharma, M. (2014). Predicting Childhood Obesity Prevention Behaviors Using Social Cognitive Theory among Upper Elementary AfricanAmerican Children -International Quarterly Of Community Health Education.

Franks, P., Hanson, R., Knowler, W., Sievers, M., Bennett, P., \& Looker, H. (2010). Childhood Obesity, Other Cardiovascular Risk Factors, and Premature Death. New England Journal Of Medicine.

Glanz, K., Rimer, B. K., \& Viswanath, K. (2014). Health Behavior And Health Education: Theory, Research And Practice (3rd edition).

Gorely, T., Biddle, S., Marshall, S., Cameron, N., \& Cassey, L. (2009). The Association between Distance to School, Physical Activity and Sedentary Behaviors in Adolescents: Project STIL.

Gunawan, J. (2015). Ensuring Trustworthiness In Qualitative Research - Belitung Nursing Journal.

Hall, K., Ayuketah, A., Brychta, R., Cai, H., Cassimatis, T., \& Chen, K. et al. (2019). Ultra-Processed Diets Cause Excess Calorie Intake and Weight Gain: An Inpatient

Hanvey AN, Mensah FK, Clifford SA, Wake M. (2017). Adolescent Cardiovascular Functional And Structural Outcomes Of Growth Trajectories From Infancy: Prospective Community-Based Study.

Health Behaviour: Psychosocial Theories. Accessed on $3^{\text {rd }}$ June, 2020. https://www.sciencedirect.com/topics/medicine-and-dentistry/social-cognitivetheory 
Hu, F. (2013). Resolved: there is sufficient scientific evidence that decreasing sugar-sweetened beverage consumption will reduce the prevalence of obesity and obesity-related diseases.

Kääriäinen, M., Kanste, O., Elo, S., Pölkki, T., Miettunen, J., \& Kyngäs, H. (2011). Testing and verifying nursing theory by confirmatory factor analysis. Journal Of Advanced Nursing.

Kaur, N., Vedel, I., El Sherif, R., \& Pluye, P. (2019). Practical mixed methods strategies used to integrate qualitative and quantitative methods in communitybased primary health care research. Family practice, 36(5), 666671.https://academic.oup.com/fampra/article/36/5/666/5388858

Lee, A., Mhurchu, C., Sacks, G., Swinburn, B., Snowdon, W., \&Vandevijvere, S. et al. (2014). Monitoring the price and affordability of foods and diets globally.

Li, F., Harmer, P., Cardinal, B., Bosworth, M., \& Johnson-Shelton, D. (2009). Obesity and the Built Environment: Does the Density of Neighborhood Fast-Food Outlets Matter?.American Journal Of Health Promotion.

Maddock, J. (2004). The Relationship between Obesity and the Prevalence of Fast Food Restaurants: State-Level Analysis. American Journal Of Health Promotion.

Marks D. F. (2015). Homeostatic theory of obesity. Health psychology open, 2(1), 2055102915590692. https://doi.org/10.1177/2055102915590692

Mazidi, M., \& Speakman, J. (2017). Higher densities of fast-food and full-service restaurants are not associated with obesity prevalence.

Mbochi, R., Kuria, E., Kimiywe, J., Ochola, S., \&Steyn, N. (2012). Predictors of overweight and obesity in adult women in Nairobi Province, Kenya. BMC Public Health.

Morbidity And Mortality Weekly Report, (2015). Recommendation Regarding Cardiovascular Disease Prevention and Control from the Community Preventive Services Task. 
Nicholas, J., Dennison, B., De Long, R., Prokorym, M., \& Brissette, I. (2009). Randomized controlled trial of a mailed toolkit to increased use of body mass index percentiles to screen for childhood obesity. Preventing Chronic Disease.

Roberta Heale, Allison Shorten; (2016). Ethical Context Of Nursing Research.The Importance of Ethics in Nursing Research. Accessed on the $3^{\text {rd }}$ June, 2020. https://www.jacksonvilleu.com/blog/nursing/the-importance-ofethics-in-nursing-research/

Strand, B., Kuh, D., Shah, I., Guralnik, J., \& Hardy, R. (2010). Childhood, adolescent and early adult body mass index in relation to adult mortality: results from the British 1946 birth cohort. Journal Of Epidemiology And Community Health.

Swinburn, B., \&Vandevijvere, S. (2016). WHO Report On Ending Childhood Obesity Echoing Earlier Recommendations. Randomized Controlled Trial of Ad Libitum Food Intake.

Templeton, M. (2014). Nursing Research: An Introduction Moule Pam and Goodman Margaret Nursing Research.

Timmins, F. (2013). Nursing Research Generating and Assessing Evidence for Nursing Practice.

Kostovski, M., Tasic, V., Laban, N., Polenakovic, M., Danilovski, D., \&Gucev, Z. (2017). Obesity in Childhood and Adolescence, Genetic Factors.

Grossoehme, D. (2014). Overview of Qualitative Research. Journal Of Health Care Chaplaincy.

Polit, D., \& Beck, C. (2012). Is there still gender bias in nursing research? An update. Research In Nursing \& Health.

Pereira, S., Seabra, A., Silva, R., Katzmarzyk, P., Beunen, G., \&Maia, J. (2010). Prevalence of overweight, obesity and physical activity levels in children from Azores Islands. 
Sandelowski, M., \& Leeman, J. (2012). Writing Usable Qualitative Health Research Findings.

Sesselberg, T., Klein, J., O'Connor, K., \& Johnson, M. (2010). Screening and counseling for childhood obesity:

Nava Turgo, N. (2010). Book Review: DAVID SILVERMAN, Doing Qualitative Research (3rd Edition).

Sorg, M., Yehle, K., Coddington, J., \& Ahmed, A. (2013). Implementing familybased childhood obesity interventions.

Staneck E.s, \&CohenN.L. (2009). Association between eating patterns and obesity in a free living US adult population.

Trost, Sirard, Dowda, Pfeiffer, and Pate (2013). For WHO; Sedentary behavior: Physical activity in Adolescent Obesity in US population.

Tyler, J., Fruh, S., \&Mulekar, M. (2014). Pediatric Obesity Screening and Prevention Strategies.

Van Sluijs EMF, Page A, Ommundsen Y, Griffin SJ. Behavioral and social correlates of sedentary time in young people.

Vasques, C., Mota, M., Correia, T., \& Lopes, V. (2012). Prevalence of overweight/obesity and its association with sedentary behavior in children.

Waterman, A. (2013). The humanistic psychology-positive psychology divide: Contrasts in philosophical foundations.

WHO, 2014.Adolescent obesity and related behaviors: trends and inequalities in the WHO European Region.

WHO,2013. Global Health Observatory Data Repository, 2013 http://apps.who.int/gho/data/view.main, accessed 21 May 2020.

WHO, regional office for Europe (2018) Body Mass Index obtained from http://www.euro.who.int/en/health-topics/disease-prevention/nutrition/a-healthylifestyle/body-mass-index-bmi

WHO, 2013. Obesity and Overweight, WHO Fact sheet. 
WHO, 2017.e-Library of Evidence for Nutrition Actions (eLENA). Interventions by global target.

WHO, 2017. Obesity and overweight Factsheet. 